\title{
Influence of climate on tree health evaluated by defoliation in the ICP level I network (Romania)
}

\author{
Ionel Popa ${ }^{(1)}$, \\ Ovidiu Badea ${ }^{(1-2)}$, \\ Diana Silaghi ${ }^{(1)}$
}

\section{Introduction}

Documentation of the deterioration of Natural Capital components at both the regional and global scale by the international scientific community (Balmford et al. 2003, 2005a, 2005b, Petersen et al. 2007) has led decision makers to place strong emphasis on adopting initiatives to stop, or reduce, the rate of biodiversity loss caused by the negative impact of human activities (Balmford et al. 2005a, Green et al. 2005). Consequently, numerous measures and action plans have been implemented to integrate existing monitoring systems to
Defoliation is the main parameter for assessing tree crown conditions, and is the result of cumulative interactions among different types of stressors, including climate, air pollution, pests and diseases, and management systems. Here, we evaluated a long-term data series (1992-2013) provided by the ICPForests Level I monitoring network $(16 \times 16 \mathrm{~km})$ in Romania. Specifically, we investigated how climate influences defoliation at different spatial and temporal levels using statistical analyses. Using periodic climatic data (mean temperature and precipitation) derived from a daily grid dataset (ROCADA) with a resolution of $0.1 \times 0.1^{\circ}(10 \times 10 \mathrm{~km})$, we quantified how climatic parameters were correlated with defoliation, which was expressed as the mean tree defoliation per plot (DEF), and the proportion of damaged trees (crown defoliation $>25 \%$ - fDEF). The cross-correlation (Spearman $r$ ) between defoliation indicators and temperature was positive and relatively constant over time for all broadleaves and conifers, combined and separately, except for Fagus sylvatica (European beech), which had a negative cross-correlation coefficient. The correlation obtained for precipitation was similar to that obtained for temperature; however, this relationship was negative (except, again, for beech). The temporal influence of temperature on defoliation was much lower than that of precipitation, which had the greatest influence in dry regions (south and southeast Romania), especially for Quercus species. Furthermore, precipitation had a positive influence in moderate climate regions for conifers that were situated outside their natural distribution ranges. For beech and conifers situated at the upper altitudinal limits, temperature was negatively correlated with defoliation, i.e., temperature had a positive influence on health status.

Keywords: Climate Change, Defoliation, Tree Species, Forest Health, Temperature, Precipitation, Level I allow ecosystem status to be assessed, in parallel to adopting new designs based on general guidelines through a "top-down" approach (Henry et al. 2008).

Throughout all terrestrial ecosystems, forests have the highest biodiversity, providing habitats for a wide range of animal and plant species. With their high potential of carbon sequestration, they constitute one of the most important elements of the global carbon cycle. Moreover, forests are the main component of rural development, providing protective functions for soil, water and infrastructure, as well as contribut-
(1) National Institute for Research and Development in Forestry "Marin Dracea" (INCDS), Eroilor 128, 077190 Voluntari (Romania); (2) Transilvania” University of Brasov, Universitatii 1, 500068 Brasov (Romania)

@ Diana Silaghi (diana.silaghi@icas.ro)

Received: Aug 18, 2016 - First Accepted: Dec 22, 2016 - Final Acceptance: Mar 29, 2017

Citation: Popa I, Badea O, Silaghi D (2017). Influence of climate on tree health evaluated by defoliation in the ICP level I network (Romania). iForest 10: 554-560. - doi: 10.3832/ifor2202009 [online 2017-05-05]

Communicated by: Silvano Fares ing goods and services to the economic sector (Ojea et al. 2010). In parallel, forest ecosystems provide essential socio-ecologdispensable for maintaining the quality of life at global, regional, and local levels. These forest ecosystem services can be maintained by ensuring their biodiversity, appropriate health status, stability, functionality, and sustainability through proper forest management (Canadell \& Raupach 2008, Obersteiner et al. 2010, Yoshikawa et al. 2011, Schaich \& Milad 2013).

Climate change, air pollution and others anthropogenic factors have a dramatic impact on forest ecosystem functions, structure and diversity (Fischer et al. 2010), as well as multiple, cumulative effects on the forest health status at local, regional and global scales (De Marco et al. 2014, Nowak et al. 2014, Bendixsen et al. 2015). Increasing ozone concentrations and biodiversity loss are also key processes that produce significant changes at the global level, such as increasing average temperatures, as well as causing an increase in the frequency of extreme events, including catastrophic droughts and floods (MEA 2005).

In the last decades, various biotic and abiotic factors causing forest decline have ical and economic benefits that are in 
been monitored at the tree, stand and forest levels through several national and international programs (Matthews et al. 2000, Badea et al. 2013). Most European countries have developed different research/long-term environmental surveys under the program "International Co-operative Programme on Assessment and Monitoring of Air Pollution Effects on Forests" (ICP-Forests) aimed at monitoring the health status of forests. Such monitoring systems, which were formerly focused on the effects of air pollution, had to be revised and reorganized to constitute a "new forest monitoring network" at the European level, using harmonized criteria and indicators of forest health status, and sharing common monitoring methods, in accordance with new environmental issues such as climate change and biodiversity conservation. This unitary approach is expected to ensure good comparability of results for long-term data series.

The health status of trees in forests in Europe is monitored over large areas by surveying the conditions of tree crowns. Indeed, defoliation is the result of cumulative interactions of various stress factors, including climate, air pollution, biotic factors, and management systems. The large-scale forest condition monitoring network (Level I) offers the opportunity to investigate the relationships between tree defoliation and climate, taking into account the large number of species and high spatial variability in their distribution (De Vries et al. 2000, Requardt et al. 2009, Fischer et al. 2012).

This study aimed to identify the main climatic drivers that have significantly influenced tree defoliation over a 22-year period (1992-2013) in the Level I forest monitoring network $(16 \times 16 \mathrm{~km})$ of Romania. In particular, we focused on: (i) analyzing long-term defoliation dynamics at the national and regional scale for all tree species, conifers vs. broadleaved species, and the main tree species; (ii) developing statistical analyses of how climate (temperature and precipitation) influences the defoliation of trees; and (ii) analyzing regional and species level variability in detail, based on the statistical relationship between climate and defoliation.

\section{Material and methods}

\section{Datasets}

Our dataset contained information on tree crown condition evaluations made across multiple years from 1992 to 2013 (except 2002 and 2008) in the ICP-Forest level I monitoring network $(16 \times 16 \mathrm{~km})$, which was established in Romanian forests in 1991. In each monitoring plot, 24 predominant, dominant, and co-dominant trees (Kraft 1884) were consistently evaluated. Between 215 and 244 plots were monitored annually (Fig. 1). Tree crown defoliation was assessed each year using a common methodology adopted by ICP-Forests (Eichorn et al. 2006, 2010). Based on this information, two defoliation indicators were calculated: the mean tree defoliation per plot (DEF) and the proportion of damaged trees (crown defoliation > $25 \%$ fDEF). These indicators were determined at the plot level for all species, groups of species (broadleaved versus coniferous species), and the main individual species: beech (Fagus sylvatica) oak species (Quercus spp.), and Norway spruce (Picea abies). To ensure there was a minimum sample size for each species (groups of species), a threshold of eight trees per plot was adopted.

Defoliation indicator datasets include both spatial (cross-sectional) and temporal (longitudinal) gradients as a consequences of different sampling locations and multiple-years evaluations. For the temporal analysis, defoliation indicators were standardized as $z$-score values based on mean and standard deviation computed at plot level for the 1992-2013 period.

\section{Climatic data}

Mean temperature and amount of precipitation were derived from the daily grid dataset ROCADA at a resolution of $0.1 \times 0.1^{\circ}$ $(10 \times 10 \mathrm{~km}$ - Dumitrescu \& Birsan 2015). Averages were computed for three periods: (i) annual mean (previous September

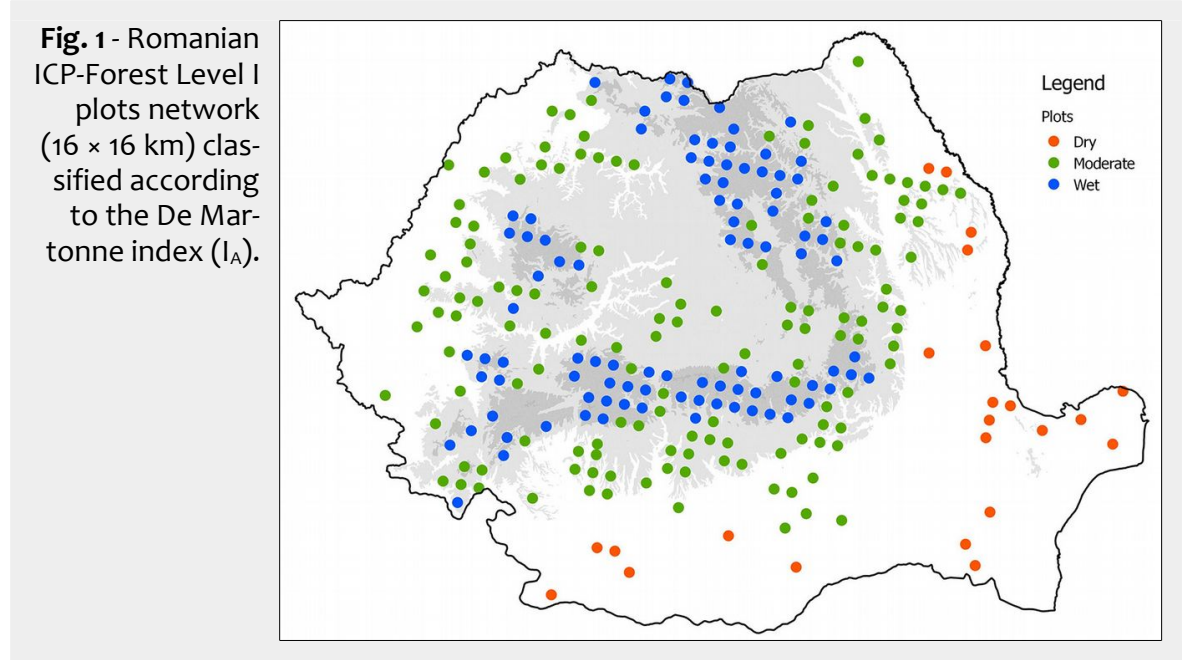

until current August - pS_A); (ii) mean of the current growing season (April to August - A_A); and (iii) the mean of the previous growing season (previous April to previous August - pA pA). Means were calculated from both raw data and z-score values, using the same standardization method described for defoliation indices.

To explore the regional differences within Romania, all plots were classified into three climatic regions according to the annual De Martonne's index $\left(I_{A}\right)$ : Dry $\left(I_{A}<26\right)$; Moderate $\left(26 \leq I_{A} \leq 45\right)$; and Wet $\left(I_{A}>45\right)$.

\section{Statistical analysis}

Potential trends in defoliation and climate were tested using the non-parametric Mann-Kendall test (Zs). Positive values of Zs indicate increasing trends, while negative $\mathrm{Zs}$ values indicate decreasing trends. If Zs $<1$ (with $p>0.05$ ), then no trend is present in the time series. To quantify the relationship between climatic parameters (temperature and precipitation) and defoliation indicators (DEF and fDEF), the nonparametric Spearman's correlation coefficient $\left(r_{s}\right)$ was used. Cross-sectional analysis was performed for each year and species (groups of species and separate species) using the raw data. The longitudinal analysis used the z-score data, both for defoliation indicators and climate data differentiated in relation to climatic region. All statistical analyses were performed using $R$ software (R Core Team 2008).

\section{Results}

\section{Trends in the defoliation indicators}

The defoliation indices considered in this study (DEF and fDEF) had similar trends over the analyzed period (1992-2013). Such general trends did not change when absolute (Fig. 2) or standardized values (Fig. 3) were considered. The maximum defoliation was recorded in the years 1994 and 2000; starting from 2003, a progressive decrease in defoliation and thus a general improvement in forest conditions was observed. The general pattern of variation over time had two components: (i) a relative constant trend until 2002; and (ii) a linear trend with a negative slope starting from 2003. Considering the two components, both defoliation indicators showed a significant negative monotonic trend $(\mathrm{Zs}=-3.16, \mathrm{p}<0.01$ and $Z s=-3.44, p<0.01$ for DEF and fDEF, respectively).

Both conifer and broadleaved species exhibited an overall decreasing trends in DEF and fDEF over time ( $p<0.01-$ Fig. 2 , Fig. 3). The trends for broadleaved species were very similar to those observed for all species, with a constant pattern being detected until 2003, and a decreasing trend thereafter $(Z s=-2.87, p<0.01$ for DEF; Zs = $-3.38, p<0.01$ for fDEF). For conifers, the defoliation rate and percentage of damaged trees tended to increase during 19951998. After 1998, a constant recovery of tree health status was noticed (up to DEF = 
Fig. 2 - Temporal dynamics of mean defoliation (DEF red line) and share of damaged trees (fDEF - blue line) based on raw data means.
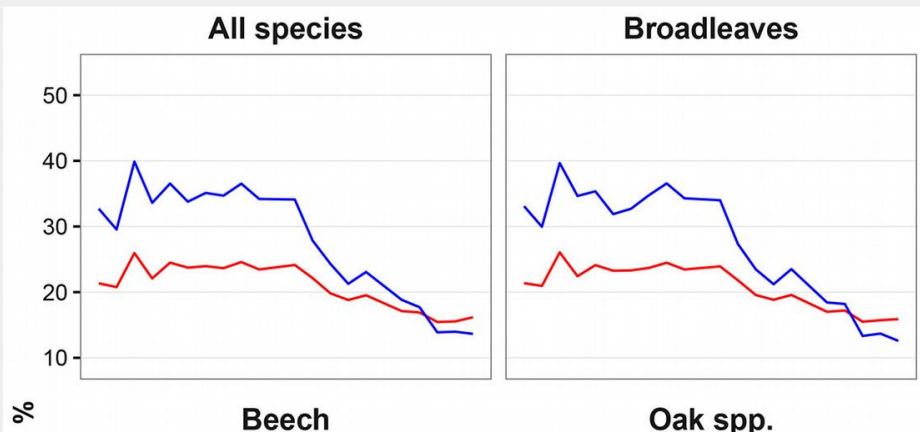

Oak spp.

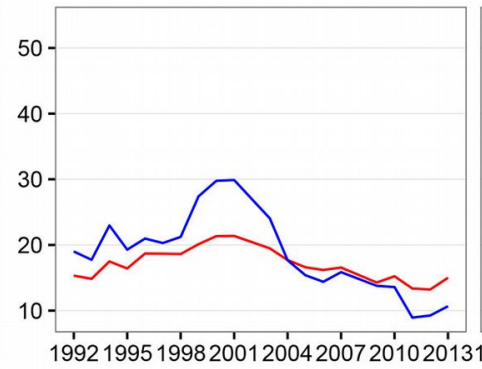

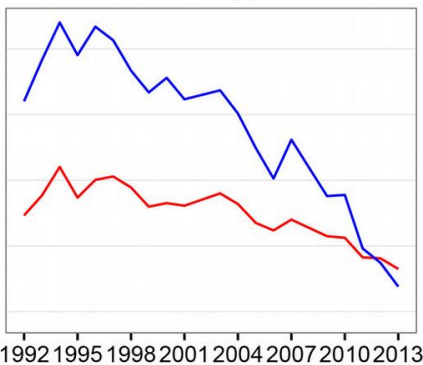

Year

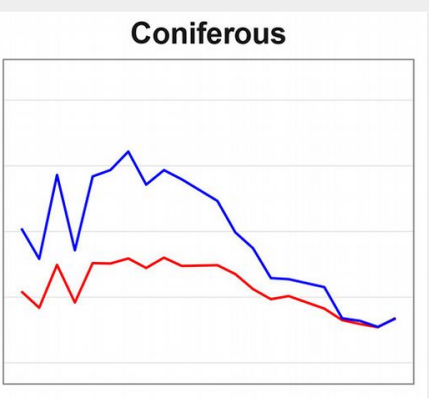

Norway spruce

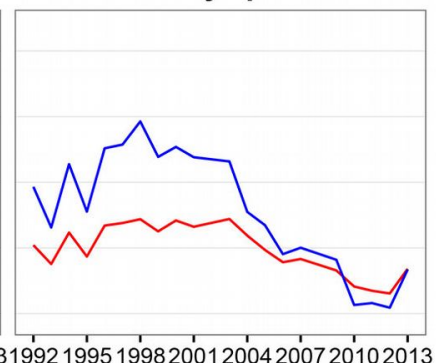

- DEF - fDEF

$16 \%$ in 2013), with this trend being negatively monotonic $(Z s=-2.76, p=0.01$ for DEF; $Z s=-3.21, p<0.01)$. The maximum DEF and $\mathrm{fDEF}$ values were recorded in different years for broadleaved and conifers (1994 and 1998, respectively).

At the individual species level, although overall DEF and fDEF trends decreased, patterns in defoliation and the percentage of damaged tree over time differed. Beech had relatively low values for DEF between 1992 and 1998 (around 18\%), followed by a deterioration in health status until 2001 (in 2000 and 2001, maximum DEF and fDEF values of $21 \%$ and $30 \%$ were recorded, respectively); however, the general trend was negative $(Z s=-2.2, p=0.03$ for $D E F, Z s=$
-2.48; $p=0.01$ for fDEF). An accelerated decreasing trend was observed from 2002 onwards. Oaks had maximum DEF and fDEF values in 1994 (32\% and 56\%, respectively) and then both health status indicators started to decrease $(\mathrm{Zs}=-3.44, \mathrm{p}<0.01$ and $Z s=-3.78, p<0.01$ for $D E F$ and $f D E F$, respectively). Yet, oaks were the species that were most affected by climate during the entire study period (Fig. 2, Fig. 3).

During 1992-2000, Norway spruce exhibited large variation in both DEF and fDEF, with high defoliation values alternating with recovery periods, leading to a generally negative trend $(Z s=-2.42, p=0.02$ for $D E F ; Z s=-2.99, p<0.01$ for fDEF). After 2000, the health status of Norway spruce improved (Fig. 2, Fig. 3).

This general pattern was reflected in all species, groups of species, and Norway spruce. However, a continuously decreasing trend was observed for oak species from 1994 onwards. Beech was the healthiest species, showing a slight increase between 1999 and 2002, followed by the same decreasing trend.

\section{Defoliation vs. temperature: spatial} correlation analysis

Variation in the cross-sectional correlation (spatial gradient) between defoliation indicators and mean temperature (previous September-current August) was positive and relatively constant over time for all
Fig. 3 - Dynamics of relative mean defoliation (DEF) and relative share of damaged trees (fDEF, z-score values).

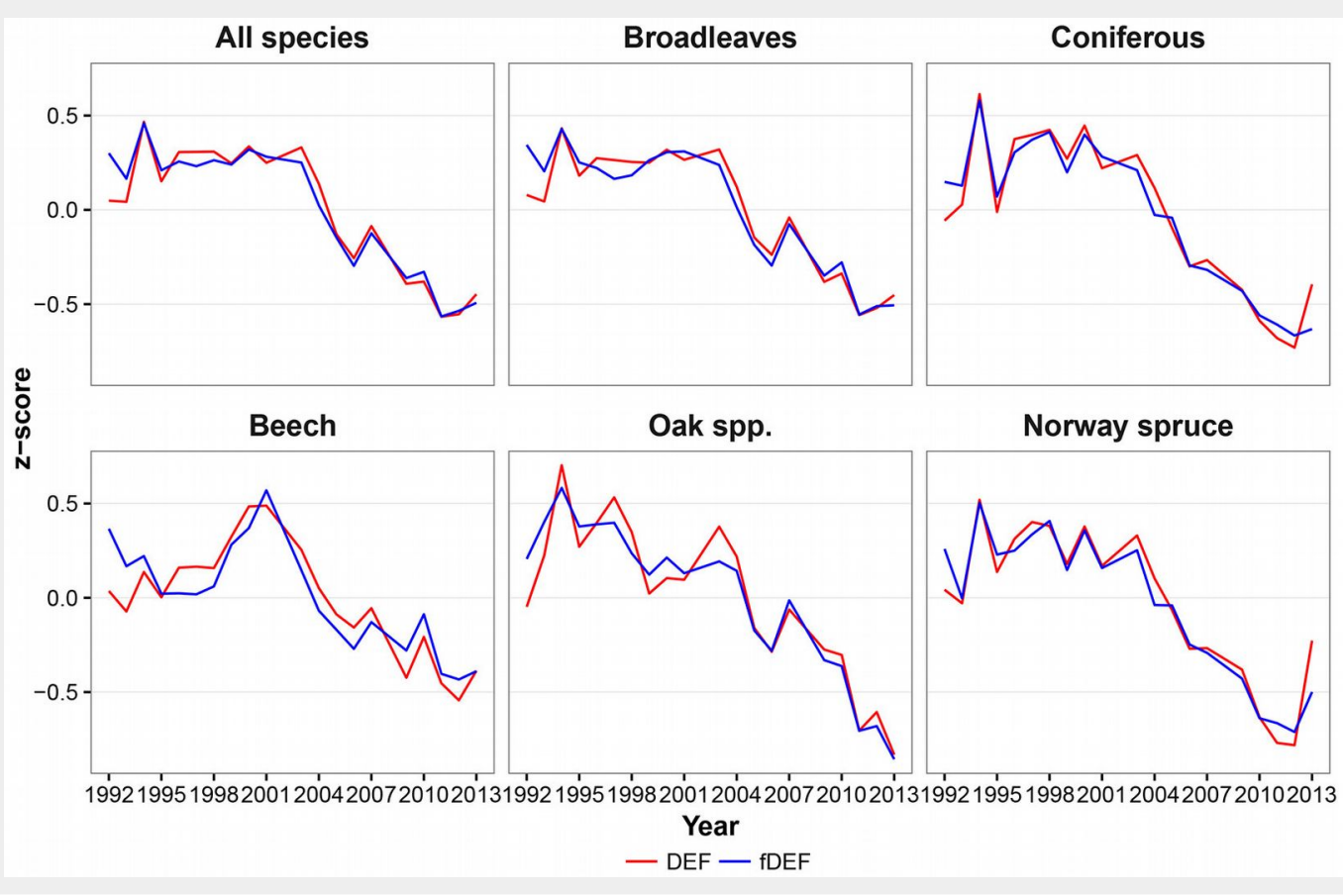


Tab. 1 - Cross-sectional Spearman's correlation coefficients $\left(r_{s}\right)$ between mean defoliation (DEF), share of damaged trees (fDEF) and annual temperature (pS_A). $\left({ }^{*}\right): p<0.05$.

\begin{tabular}{|c|c|c|c|c|c|c|c|c|c|c|c|c|}
\hline \multirow[b]{2}{*}{ Year } & \multicolumn{3}{|c|}{ DEF vs. Annual Temperature } & \multicolumn{9}{|c|}{ fDEF vs. Annual Temperature } \\
\hline & $\begin{array}{c}\text { All } \\
\text { species }\end{array}$ & $\begin{array}{l}\text { Broad- } \\
\text { leaves }\end{array}$ & Conifers & Beech & $\begin{array}{l}\text { Oak } \\
\text { spp. }\end{array}$ & $\begin{array}{l}\text { Norway } \\
\text { spruce }\end{array}$ & $\begin{array}{c}\text { All } \\
\text { species }\end{array}$ & $\begin{array}{l}\text { Broad- } \\
\text { leaves }\end{array}$ & Conifers & Beech & $\begin{array}{l}\text { Oak } \\
\text { spp. }\end{array}$ & $\begin{array}{l}\text { Norway } \\
\text { spruce }\end{array}$ \\
\hline 1992 & $0.220^{*}$ & $0.305^{*}$ & -0.008 & -0.002 & 0.122 & -0.118 & $0.220^{*}$ & $0.309^{*}$ & -0.055 & 0.031 & 0.153 & -0.152 \\
\hline 1993 & $0.272^{*}$ & $0.341^{*}$ & -0.184 & -0.026 & 0.297 & -0.214 & $0.269^{*}$ & $0.347^{*}$ & -0.163 & -0.076 & 0.335 & -0.204 \\
\hline 1994 & $0.314^{*}$ & $0.385^{*}$ & 0.152 & -0.119 & 0.008 & 0.041 & $0.292^{*}$ & $0.371^{*}$ & 0.104 & -0.105 & 0.159 & -0.034 \\
\hline 1995 & $0.236^{*}$ & $0.307^{*}$ & -0.231 & -0.139 & 0.189 & $-0.347^{*}$ & $0.239^{*}$ & $0.319^{*}$ & -0.236 & -0.139 & 0.147 & $-0.341^{*}$ \\
\hline 1996 & $0.223^{*}$ & $0.272^{*}$ & 0.207 & -0.161 & 0.084 & 0.011 & $0.227^{*}$ & $0.288^{*}$ & 0.131 & -0.120 & 0.064 & -0.015 \\
\hline 1997 & $0.196^{*}$ & $0.254^{*}$ & $0.283^{*}$ & $-0.259^{*}$ & 0.105 & 0.064 & $0.179^{*}$ & $0.270^{*}$ & 0.164 & $-0.205^{*}$ & 0.146 & -0.019 \\
\hline 1998 & $0.208^{*}$ & $0.294^{*}$ & 0.226 & -0.164 & 0.239 & -0.030 & $0.177^{*}$ & $0.280^{*}$ & 0.120 & -0.135 & 0.282 & -0.068 \\
\hline 1999 & 0.104 & 0.109 & 0.220 & $-0.322^{*}$ & 0.152 & 0.063 & 0.104 & 0.101 & 0.133 & $-0.333^{*}$ & 0.174 & -0.019 \\
\hline 2000 & 0.080 & 0.103 & $0.255^{*}$ & $-0.296^{*}$ & 0.200 & 0.064 & 0.094 & 0.102 & 0.225 & $-0.326^{*}$ & 0.177 & 0.041 \\
\hline 2001 & 0.032 & 0.004 & $0.329^{*}$ & $-0.296^{*}$ & 0.024 & 0.205 & 0.052 & 0.015 & $0.288^{*}$ & $-0.255^{*}$ & 0.032 & 0.137 \\
\hline 2003 & 0.117 & 0.129 & $0.322^{*}$ & $-0.283^{*}$ & 0.090 & 0.249 & $0.137^{*}$ & 0.138 & $0.268^{*}$ & $-0.245^{*}$ & 0.096 & 0.210 \\
\hline 2004 & $0.133^{*}$ & $0.169^{*}$ & $0.342^{*}$ & -0.190 & -0.071 & 0.220 & $0.160^{*}$ & $0.178^{*}$ & $0.373^{*}$ & -0.167 & -0.076 & 0.195 \\
\hline 2005 & 0.113 & $0.156^{*}$ & $0.320^{*}$ & -0.194 & 0.014 & 0.146 & 0.108 & $0.148^{*}$ & $0.344^{*}$ & -0.180 & -0.012 & 0.159 \\
\hline 2006 & 0.079 & 0.083 & $0.325^{*}$ & $-0.289^{*}$ & 0.031 & 0.230 & 0.105 & 0.104 & $0.368^{*}$ & $-0.232^{*}$ & 0.050 & 0.271 \\
\hline 2007 & $0.139^{*}$ & 0.129 & 0.247 & $-0.250^{*}$ & -0.064 & 0.229 & $0.166^{*}$ & $0.169^{*}$ & $0.279^{*}$ & $-0.222^{*}$ & -0.095 & 0.315 \\
\hline 2009 & 0.019 & -0.001 & $0.274^{*}$ & $-0.432^{*}$ & 0.059 & 0.260 & 0.062 & 0.042 & 0.217 & $-0.283^{*}$ & 0.022 & 0.282 \\
\hline 2010 & -0.010 & -0.063 & 0.249 & $-0.504^{*}$ & 0.160 & 0.202 & 0.053 & 0.002 & $0.298^{*}$ & $-0.374^{*}$ & 0.214 & 0.196 \\
\hline 2011 & 0.005 & -0.044 & $0.294^{*}$ & $-0.465^{*}$ & 0.185 & 0.274 & 0.011 & -0.036 & $0.339^{*}$ & $-0.407^{*}$ & 0.148 & $0.407^{*}$ \\
\hline 2012 & 0.100 & 0.040 & $0.364^{*}$ & $-0.411^{*}$ & 0.139 & 0.272 & 0.055 & 0.011 & $0.405^{*}$ & $-0.353^{*}$ & 0.116 & $0.435^{*}$ \\
\hline 2013 & 0.074 & 0.056 & 0.242 & -0.025 & 0.056 & $0.314^{*}$ & 0.032 & 0.044 & 0.239 & -0.100 & 0.047 & 0.236 \\
\hline
\end{tabular}

species. Significant values were observed correlated with temperature; however, sig- and fDEF were negatively correlated with at the start of the study period (1992-1998) nificant relationships $\left(r_{s}=0.274-0.364, p<\right.$ mean temperature in all years, with signifiand for two individual years (2004 and 0.05) were only detected in the second cant relationships first being detected 2007, $r_{s}=0.133-0.314, p<0.05-$ Tab. 1). For part of the study period (Tab. 1). The de- from 1997 onwards, except for 1998,2004, broadleaved species, a similar trend was tected significance for the fDEF-tempera- 2005, and 2013 (Tab. 1). In the case of oak observed across species, with higher corre- ture correlation was similar to the detected species, DEF did not appear to be influlation coefficients being detected in 1992- significance for the DEF-temperature corre- enced by temperature in any way. The only $1998\left(r_{s}=0.254-0.385, p<0.05\right)$. Also, in lation for all species, broadleaves and coni- significant correlation was that between 2004 and 2005, the mean defoliation of fers combined.

broadleaved species was significantly cor- At the individual species level, the defolia- 0.33 related with temperature, with the inten- tion-temperature relationship differed to $w$

sity of this relationship decreasing over that observed for all species or major spe- Norway spruce exhibited a significant cortime. For conifers, DEF was also positively cies groups. For Fagus sylvatica, both DEF relation between DEF and mean tempera-

Tab. 2 - Cross-sectional Spearman's correlation coefficients $\left(r_{s}\right)$ between defoliation (DEF), share of damaged trees (fDEF) and annual amount of precipitation. (*): $\mathrm{p}<0.05$.

\begin{tabular}{|c|c|c|c|c|c|c|c|c|c|c|c|c|}
\hline \multirow[b]{2}{*}{ Year } & \multicolumn{6}{|c|}{ DEF vs. Precipitation } & \multicolumn{6}{|c|}{ fDEF vs. Precipitation } \\
\hline & $\begin{array}{c}\text { All } \\
\text { species }\end{array}$ & $\begin{array}{l}\text { Broad- } \\
\text { leaves }\end{array}$ & Conifers & Beech & $\begin{array}{l}\text { Quercus } \\
\text { spp. }\end{array}$ & $\begin{array}{l}\text { Norway } \\
\text { spruce }\end{array}$ & $\begin{array}{c}\text { All } \\
\text { species }\end{array}$ & $\begin{array}{l}\text { Broad- } \\
\text { leaves }\end{array}$ & Conifers & Beech & $\begin{array}{l}\text { Quercus } \\
\text { spp. }\end{array}$ & $\begin{array}{l}\text { Norway } \\
\text { spruce }\end{array}$ \\
\hline 1992 & $-0.304^{*}$ & $-0.401^{*}$ & 0.026 & -0.003 & $-0.561^{*}$ & 0.077 & $-0.284^{*}$ & $-0.374^{*}$ & 0.025 & 0.089 & $-0.528^{*}$ & 0.088 \\
\hline 1993 & $-0.228^{*}$ & $-0.274^{*}$ & -0.041 & 0.065 & -0.298 & 0.002 & $-0.205^{*}$ & $-0.253^{*}$ & -0.068 & 0.173 & -0.295 & -0.015 \\
\hline 1994 & $-0.325^{*}$ & $-0.370^{*}$ & -0.134 & 0.083 & -0.248 & 0.199 & $-0.292^{*}$ & $-0.337^{*}$ & -0.137 & 0.134 & -0.282 & 0.211 \\
\hline 1995 & -0.075 & $-0.157^{*}$ & $0.310^{*}$ & $0.240^{*}$ & -0.032 & $0.402^{*}$ & -0.081 & $-0.163^{*}$ & $0.293^{*}$ & $0.252^{*}$ & 0.056 & $0.407^{*}$ \\
\hline 1996 & $-0.151^{*}$ & $-0.239^{*}$ & 0.100 & $0.208^{*}$ & $-0.374^{*}$ & 0.269 & $-0.144^{*}$ & $-0.236^{*}$ & 0.111 & $0.227^{*}$ & $-0.318^{*}$ & 0.265 \\
\hline 1997 & -0.056 & -0.133 & 0.076 & $0.295^{*}$ & -0.120 & 0.273 & -0.047 & -0.123 & 0.099 & $0.298^{*}$ & -0.075 & 0.244 \\
\hline 1998 & $-0.210^{*}$ & $-0.323^{*}$ & 0.044 & 0.065 & $-0.424^{*}$ & 0.235 & $-0.189^{*}$ & $-0.313^{*}$ & 0.067 & 0.040 & $-0.418^{*}$ & 0.266 \\
\hline 1999 & $-0.175^{*}$ & $-0.239^{*}$ & -0.028 & 0.017 & $-0.451^{*}$ & 0.138 & $-0.153^{*}$ & $-0.202^{*}$ & -0.059 & 0.074 & $-0.480^{*}$ & 0.099 \\
\hline 2000 & $-0.205^{*}$ & $-0.215^{*}$ & $-0.355^{*}$ & -0.014 & $-0.317^{*}$ & -0.117 & $-0.171^{*}$ & $-0.159^{*}$ & $-0.280^{*}$ & 0.080 & $-0.345^{*}$ & -0.105 \\
\hline 2001 & -0.108 & -0.140 & -0.011 & -0.026 & -0.239 & 0.179 & -0.075 & -0.095 & 0.031 & -0.003 & -0.205 & 0.261 \\
\hline 2003 & $-0.159^{*}$ & $-0.143^{*}$ & -0.253 & 0.067 & -0.053 & -0.221 & $-0.172^{*}$ & $-0.145^{*}$ & $-0.280^{*}$ & 0.075 & -0.103 & -0.167 \\
\hline 2004 & $-0.168^{*}$ & $-0.206^{*}$ & -0.119 & -0.124 & -0.043 & 0.078 & $-0.194^{*}$ & $-0.206^{*}$ & -0.206 & -0.138 & 0.001 & -0.024 \\
\hline 2005 & $-0.138^{*}$ & $-0.183^{*}$ & -0.055 & 0.003 & -0.208 & 0.138 & $-0.172^{*}$ & $-0.209^{*}$ & -0.119 & -0.110 & -0.124 & 0.061 \\
\hline 2006 & $-0.188^{*}$ & $-0.207^{*}$ & -0.185 & -0.059 & -0.157 & 0.035 & $-0.209^{*}$ & $-0.203^{*}$ & -0.250 & -0.062 & -0.134 & -0.123 \\
\hline 2007 & $-0.269^{*}$ & $-0.248^{*}$ & $-0.343^{*}$ & -0.148 & 0.149 & -0.188 & $-0.299^{*}$ & $-0.279^{*}$ & $-0.447^{*}$ & -0.159 & 0.155 & $-0.320^{*}$ \\
\hline 2009 & -0.128 & -0.131 & -0.176 & -0.043 & 0.089 & -0.014 & $-0.158^{*}$ & $-0.146^{*}$ & -0.216 & -0.112 & 0.140 & -0.031 \\
\hline 2010 & $-0.213^{*}$ & $-0.189^{*}$ & $-0.373^{*}$ & -0.107 & $-0.279^{*}$ & -0.167 & $-0.195^{*}$ & $-0.157^{*}$ & $-0.378^{*}$ & -0.076 & -0.218 & -0.154 \\
\hline 2011 & $-0.165^{*}$ & -0.131 & $-0.375^{*}$ & 0.025 & -0.252 & -0.243 & -0.097 & -0.072 & $-0.294^{*}$ & 0.134 & -0.264 & -0.159 \\
\hline 2012 & $-0.162^{*}$ & -0.112 & $-0.328^{*}$ & 0.134 & 0.052 & -0.202 & -0.117 & -0.103 & -0.225 & 0.125 & -0.068 & -0.137 \\
\hline 2013 & $-0.302^{*}$ & $-0.281^{*}$ & $-0.350^{*}$ & $-0.272^{*}$ & -0.244 & $-0.316^{*}$ & $-0.202^{*}$ & $-0.179^{*}$ & $-0.349^{*}$ & -0.135 & -0.176 & -0.292 \\
\hline
\end{tabular}


ture in $1995\left(r_{s}=-0.347, p<0.05\right)$ and 2013 $\left(r_{s}=0.314, p<0.05\right)$. In the case of fDEF, the correlation was stronger, with statistically significant relationships being detected in 1995 and 2011-2012 (Tab. 1).

\section{Defoliation vs. precipitation: spatial correlation analysis}

For all species, both DEF and fDEF were negatively correlated with precipitation in all analyzed years, except for 1995, 1997, and 2001 for both indicators and 2009 for DEF and 2011-2012 for fDEF (Tab. 2). Significant values of $r_{s}(p<0.05)$ ranged between -0.151 (1996) and -0.304 (1992) for DEF, and between -0.144 (1996) and -0.299 (2007) for $\mathrm{fDEF}$. Similar to the defoliation-temperature relationship, broadleaves exhibited the same trend as that detected for all species, with significant negative correlations being recorded in 1992-1996, 19982000, 2003-2007, 2010, and 2013 for DEF and in the same years for fDEF, excluding 2010 (Tab. 2). Defoliation indicators for conifers showed a mixed response to precipitation. In the first part of the study period, rs values were mainly positive, but were not significant or very close to zero. From 1995 , rs values became statistically significant $\left(r_{s}=0.310\right.$ for DEF and 0.293 for fDEF). From 1999, rs became negative. Statistically significant values were detected in 2000, 2007, and 2010-2013 for DEF and 2000, 2003, 2007, 2010-2011, and 2013 for fDEF (Tab. 2).

The defoliation-precipitation relationship for individual species followed the same trends detected for their corresponding species group, except for beech. For this species, both DEF and fDEF were positively correlated with the amount of precipitation during 1995-1997. After 2000, rs values became negative, reflecting the trend detected for the other broadleaved species.

\section{Defoliation vs. climate: temporal correlation analysis}

The dry region (southeastern Romania) was characterized by $\mathrm{I}_{\mathrm{A}}<26$ and predominant broadleaved species. In this region, the mean temperature of the previous growing season (t_pA_pA - April to August) was negatively correlated with $D E F$ and $\mathrm{FDEF}$ for all species and broadleaved species (Tab. 3, Tab. 4), fDEF was also sensitive to annual mean temperature (t_pS_A - previous September to current August). The correlation between temperature recorded during the previous and current growing seasons and the health of conifers (DEF and fDEF) situated in a dry climate region (outside their natural area) was significantly positive $\left(r_{s}=0.471\right.$ and 0.486 , respectively - Tab. 3, Tab. 4).

As expected, the precipitation deficit has the greatest influence on the defoliation indicators of all species, broadleaved species, and oaks. The highest Spearman's correlation coefficients were observed for the precipitation that accumulated during the year (p_pS_A), and precipitation in the cur-
Tab. 3 - Spearman's correlation coefficients $\left(r_{s}\right)$ between relative mean defoliation $(D E F)$ and climatic variables at the regional level. $(*): p<0.05$.

\begin{tabular}{llllllll}
\hline $\begin{array}{l}\text { Climate } \\
\text { variable }\end{array}$ & Region & $\begin{array}{c}\text { All } \\
\text { species }\end{array}$ & $\begin{array}{c}\text { Broad- } \\
\text { leaves }\end{array}$ & Conifers & Beech & $\begin{array}{c}\text { Quercus } \\
\text { ssp. }\end{array}$ & $\begin{array}{c}\text { Norway } \\
\text { spruce }\end{array}$ \\
\hline t_A_A & Dry & -0.006 & -0.010 & 0.197 & - & 0.005 & - \\
& Moderate & $-0.120^{*}$ & $-0.119^{*}$ & $-0.145^{*}$ & $-0.085^{*}$ & $-0.154^{*}$ & -0.066 \\
& Wet & $-0.133^{*}$ & $-0.090^{*}$ & $-0.186^{*}$ & $-0.079^{*}$ & - & $-0.213^{*}$ \\
\hline P_A_A & Dry & $-0.234^{*}$ & $-0.247^{*}$ & -0.036 & - & $-0.439^{*}$ & - \\
& Moderate & $-0.087^{*}$ & $-0.073^{*}$ & $-0.143^{*}$ & -0.057 & -0.034 & $-0.189^{*}$ \\
& Wet & $-0.086^{*}$ & $-0.070^{*}$ & $-0.128^{*}$ & $-0.072^{*}$ & - & $-0.117^{*}$ \\
\hline t_pS_A & Dry & -0.084 & -0.082 & 0.027 & - & -0.097 & - \\
& Moderate & $-0.125^{*}$ & $-0.120^{*}$ & $-0.175^{*}$ & $-0.074^{*}$ & $-0.154^{*}$ & -0.127 \\
& Wet & $-0.124^{*}$ & $-0.083^{*}$ & $-0.185^{*}$ & $-0.073^{*}$ & - & $-0.190^{*}$ \\
\hline P_pS_A & Dry & $-0.274^{*}$ & $-0.295^{*}$ & 0.020 & - & $-0.434^{*}$ & - \\
& Moderate & $-0.084^{*}$ & $-0.071^{*}$ & $-0.123^{*}$ & -0.058 & -0.034 & $-0.187^{*}$ \\
& Wet & $-0.091^{*}$ & $-0.080^{*}$ & $-0.122^{*}$ & $-0.085^{*}$ & - & $-0.114^{*}$ \\
\hline t_pA_pA & Dry & $-0.181^{*}$ & $-0.219^{*}$ & $0.471^{*}$ & - & -0.178 & - \\
& Moderate & $-0.098^{*}$ & $-0.090^{*}$ & $-0.125^{*}$ & -0.016 & $-0.103^{*}$ & -0.055 \\
& Wet & $-0.100^{*}$ & -0.048 & $-0.183^{*}$ & -0.045 & - & $-0.201^{*}$ \\
\hline p_pA_pA & Dry & $-0.021^{*}$ & -0.001 & -0.281 & - & -0.050 & - \\
& Moderate & $-0.104^{*}$ & $-0.094^{*}$ & $-0.187^{*}$ & $-0.079^{*}$ & $-0.132^{*}$ & $-0.214^{*}$ \\
& Wet & $-0.127^{*}$ & $-0.118^{*}$ & $-0.144^{*}$ & $-0.104^{*}$ & - & $-0.149^{*}$ \\
\hline
\end{tabular}

rent growing season ( $\mathrm{p} A \mathrm{~A})$. For conifers situated outside their natural area (dry climate regions) precipitation in the previous and current growing seasons (p_pA A and P_A_A) had a strong (but non-significant) influence on DEF and fDEF (Tab. 3, Tab. 4).

Precipitation had a similar influence on broadleaved species in the moderate and wet climatic regions (Tab. 3, Tab. 4). For conifers, especially Norway spruce, this influence was slightly higher in moderate than in wet climatic regions. On the other hand, oak species (which are more adapted to dry climates) were less affected by precipitation compared to other broadleaves. In moderate climate regions, where

sessile oak (Quercus petraea) is the dominant species, temperature had a minor influence $\left(r_{s}=-0.103\right.$ to $\left.-0.154, p<0.05\right)$. For beech, the mean temperature in the current growing season (t_A_A) and throughout the entire year ( $t$ p $\mathrm{SS}_{-}^{-} \mathrm{A}$ ) had a similar minor (but statistically significant) influence in moderate and wet climate regions (Tab. 3, Tab. 4). In general, the crown condition of conifers, and especially Norway spruces situated in wet climate regions, was negatively correlated with temperature indicators, with $r_{s}$ having statistically significant values between -0.188 and -0.216 (Tab. 3, Tab. 4).

Tab. 4 - Spearman's correlation $\left(r_{s}\right)$ between relative share of damaged trees ( $\left.f D E F\right)$ and climatic variables at the regional level. $(*): p<0.05$.

\begin{tabular}{llllllll}
\hline $\begin{array}{l}\text { Climate } \\
\text { Variable }\end{array}$ & Region & $\begin{array}{c}\text { All } \\
\text { species }\end{array}$ & $\begin{array}{c}\text { Broad- } \\
\text { leaves }\end{array}$ & Conifers & Beech & $\begin{array}{c}\text { Quercus } \\
\text { ssp. }\end{array}$ & $\begin{array}{c}\text { Norway } \\
\text { spruce }\end{array}$ \\
\hline t_A_A & Dry & -0.054 & -0.067 & 0.229 & - & -0.043 & - \\
& Moderate & $-0.137^{*}$ & $-0.129^{*}$ & $-0.175^{*}$ & $-0.093^{*}$ & $-0.148^{*}$ & -0.105 \\
& Wet & $-0.118^{*}$ & $-0.065^{*}$ & $-0.190^{*}$ & -0.036 & - & $-0.216^{*}$ \\
\hline P_A_A & Dry & $-0.277^{*}$ & $-0.288^{*}$ & -0.150 & - & $-0.415^{*}$ & - \\
& Moderate & $-0.081^{*}$ & $-0.080^{*}$ & -0.079 & $-0.085^{*}$ & -0.044 & -0.105 \\
& Wet & $-0.087^{*}$ & $-0.079^{*}$ & $-0.104^{*}$ & $-0.088^{*}$ & - & $-0.101^{*}$ \\
\hline t_pS_A & Dry & $-0.126^{*}$ & $-0.130^{*}$ & 0.021 & - & -0.178 & - \\
& Moderate & $-0.136^{*}$ & $-0.129^{*}$ & $-0.171^{*}$ & -0.023 & $-0.147^{*}$ & $-0.154^{*}$ \\
& Wet & $-0.104^{*}$ & -0.054 & $-0.172^{*}$ & -0.024 & - & $-0.188^{*}$ \\
P_pS_A & Dry & $-0.312^{*}$ & $-0.334^{*}$ & 0.012 & - & $-0.362^{*}$ & - \\
& Moderate & $-0.090^{*}$ & $-0.086^{*}$ & -0.093 & $-0.110^{*}$ & -0.045 & -0.134 \\
& Wet & $-0.097^{*}$ & $-0.094^{*}$ & $-0.111^{*}$ & $-0.107^{*}$ & - & $-0.095^{*}$ \\
t_pA_pA & Dry & $-0.214^{*}$ & $-0.256^{*}$ & $0.486^{*}$ & - & -0.145 & - \\
& Moderate & $-0.118^{*}$ & $-0.107^{*}$ & $-0.163^{*}$ & -0.023 & $-0.106^{*}$ & -0.131 \\
& Wet & $-0.097^{*}$ & -0.036 & $-0.185^{*}$ & -0.024 & - & $-0.205^{*}$ \\
P_pA_pA & Dry & -0.003 & $-0.334^{*}$ & -0.293 & - & -0.001 & - \\
& Moderate & $-0.104^{*}$ & $-0.086^{*}$ & $-0.143^{*}$ & $-0.109^{*}$ & $-0.112^{*}$ & $-0.148^{*}$ \\
& Wet & $-0.111^{*}$ & $-0.094^{*}$ & $-0.129^{*}$ & $-0.079^{*}$ & - & $-0.122^{*}$ \\
\hline
\end{tabular}




\section{Discussion}

The defoliation indicators obtained from data collected at the level I plots $(16 \times 16$ $\mathrm{km}$ ) produced similar trends to those recorded for the national network $(4 \times 4$ $\mathrm{km}-\mathrm{e} \%<2 \%, \mathrm{p}>0.05)$, but with higher values (Badea et al. 2003). Also, at the European level, with the exception of Norway spruce, all individual species exhibited an increase in mean defoliation until the mid1990s; however, defoliation then stabilized until 2013, with the highest levels being recorded in 2004. The overall trend slightly increased for all species from 1991 to 2013 (Michel \& Seidling 2014).

In general, temperature and precipitation had a similar influence on tree health, with a negative relationship being detected for all species and for broadleaved and coniferous species, except beech. The small influence of precipitation on the health status of beech demonstrates that this species grows well both in moderate and wet climate regions. Furthermore, beech is the most stable and healthiest species at a national level (Badea et al. 2013).

Based on our results, at the regional level temperature had a much lower effect on forest health conditions compared to precipitation. In general, the correlation coefficient values were negative, with the highest values being recorded for all species and broadleaved species situated in the dry climate regions. This is mainly due to the temperature recorded in previous growing seasons, which contribute to the development of full foliar buds. A similar trend was detected for Quercus spp., whose defoliation showed negative correlation coefficients with temperature in most cases. This means that an increase of temperature has improved oak tree health, mainly in high hills and sub-mountainous regions (the optimum area for beech).

In conifers, the positive relationship of the observed defoliation with temperature might be explained by the sensitivity of conifers established outside their natural area, especially at low altitude (Badea et al. 2013). Indeed, a negative influence of temperature on tree health was observed for Norway spruce, while precipitation had a positive effect. The positive relationship between temperature and conifer defoliation in dry climate regions reflects the response of trees to thermal stress by reducing foliar biomass. Thus, the loss of needles represents an adaptation mechanism in response to prolonged high temperature (De La Cruz et al. 2014). In the wet climate region, an increase in temperature prolongs the growing season and enhances the vegetation (and crown) condition of conifers situated at the upper altitudinal forest limit. A similar health status was recorded for conifers situated in the moderate climate region, with the influence of temperature being combined with that of precipitation.

Similar relationships between climatic variables and mean tree defoliation have been reported for regions with a similar climate to Romania. For example, in France, Ferretti et al. (2014) showed that precipitation and precipitation deficits were the factors that were mainly correlated with defoliation changes in ICP Forests Level II RENECOFOR plots. In contrast, in southern Europe, thermal stressors (temperature from April and June of the current and previous years) were the main climatic factors determining an increase in mean defoliation of trees in ICP-Forests level I plots, with synchronized response (De La Cruz et al. 2014). Further, in northern Europe, tree species showed a strong response to both biotic and abiotic factors (Nevalainen \& YliKojola 2000) and air pollutants (Ozolincius et al. 2005).

According to the latest IPCC report (IPCC 2013), an increase in water deficit and temperature in southern and eastern Romania is likely. Recent studies confirm the trend towards greater aridity in south Romania, with consequences on the stability of agricultural and forestry ecosystems being expected (Paltineanu et al. 2009). An increase in the intensity and frequency of drought will cause the health status of oak species to deteriorate, especially in the southern and southeastern parts of Romania. This phenomenon will have a significant influence on the stability of the forest ecosystem in this region.

\section{Conclusions}

In this study the health status of Romanian forests in the period 1992-2013 was analyzed based on data collected at the ICP level I network plots. Similar trends in the intensity of defoliation across years were observe using both the percentage of damaged trees (defoliation > 25\%) and the percentage of mean defoliation at the plot level. For all species, groups of species (broadleaves and conifers), and individual species, defoliation was slightly positively correlated with temperature and was negatively correlated with precipitation, except for Norway spruce and European beech. For these two species, temperature had a positive effect on trees within the natural distribution range area and at the upper altitudinal limit. Outside of their natural ranges, precipitation had a slightly positive influence, while temperature had a negative effect on defoliation for both species.

Temperature had a much lower influence on defoliation compared to precipitation. In dry regions (south and southeast), where the most Quercus spp. (except sessile oak) are located, precipitation that accumulated during the previous and current growing seasons had the greatest influence. In these regions, temperature also had a slightly positive influence in the previous growing season. In moderate climate regions, precipitation strongly influenced the health status of Norway spruce and other conifers located outside their natural distributional ranges (i.e., other than in wet climate regions). In these moderate climate regions, temperature had a lower influence on defoliation compared to wet climate regions, and prolonged the growing season, which enhanced the health status of beech, spruce, and other conifers situated at the upper altitudinal range limit of these species. Both precipitation and temperature minimally influenced beech located in the optimum area (i.e., high hills and sub-mountain regions).

Although at the national level raising temperatures and lower precipitation associated with climate change are not limiting factors triggering high levels of defoliation, our research showed an increasing negative effect of prolonged drought on the tree health status in Southern and SouthEastern part of Romania, which can lead in time to losses in the biodiversity of these forest ecosystems.

\section{Acknowledgements}

We acknowledge the financial support provided by the Romanian National Authority for Scientific Research and Innovation through Nucleu Programme GEDEFOR (PNo9460116), and the technical support provided by the Romanian Public Authority for Forestry, ICP-Forests, National Forest Administration-ROMSILVA, and National Administration for Meteorology. We also thank all the people of the forest monitoring team from INCDS "Marin Drăcea" for their assistance.

\section{References}

Badea O, Patrascoiu N, Tanase M (2003). Forest monitoring sistem in Romania - Dynamics of Romanian forest health status over the period 1990-2002. Analele ICAS 46: 221-228.

Badea O, Silaghi D, Neagu S, Taut I, Leca S (2013). Forest monitoring - assessment, analysis and warning system for forest ecosystem status. Notulae Botanicae Horti Agrobotanici Cluj-Napoca 41 (2): 613-625.

Balmford A, Bennun L, Brink BT, Cooper D, Côte IM, Crane P, Dobson A, Dudley N, Dutton I, Green RE, Gregory RD, Harrison J, Kennedy ET, Kremen C, Leader-Williams N, Lovejoy TE, Mace G, May R, Mayaux P, Morling P, Phillips J, Redford K, Ricketts TH, Rodríguez JP, Sanjayan M, Schei PJ, Van Jaarsveld AS, Walther BA (2005a). The convention on biological diversity's 2010 target. Science 307 (5707): 212-213. - doi: 10.112 6/science. 1106281

Balmford A, Crane P, Dobson A, Green RE, Mace GM (2005b). The 2010 challenge: data availability, information needs and extraterrestrial insights. Philosophical Transactions of the Royal Society B: Biological Sciences 360 (1454): 221228. - doi: 10.1098/rstb.2004.1599

Balmford A, Green RE, Jenkins M (2003). Measuring the changing state of nature. Trends in Ecology and Evolution 18 (7): 326-330. - doi: 10.1016/S0169-5347(03)00067-3

Bendixsen DP, Hallgren SW, Frazier AE (2015). Stress factors associated with forest decline in xeric oak forests of south-central United States. Forest Ecology and Management 347: 40-48. - doi: 10.1016/j.foreco.2015.03.015 
Canadell JG, Raupach MR (2008). Managing forests for climate change mitigation. Science 320 (5882): 1456-1457. - doi: 10.1126/science.115 5458

De La Cruz AC, Gil PM, Fernández-Cancio A, Minaya $M$, Navarro-Cerrillo RM, Sánchez-Salguero R, Grau JM (2014). Defoliation triggered by climate induced effects in Spanish ICP Forests monitoring plots. Forest Ecology and Management 331: 245-255. - doi: 10.1016/j.foreco.2014. 08.010

De Marco A, Proietti C, Cionni I, Fischer R, Screpanti A, Vitale M (2014). Future impacts of nitrogen deposition and climate change scenarios on forest crown defoliation. Environmental Pollution 194: 171-180. - doi: 10.1016/j.envpol.20 14.07.027

De Vries W, Klap J, Erisman JW (2000). Effects of environmental stress on forest crown condition in Europe. Part I: hypotheses and approach to the study. Water, Air and Soil Pollution 119: 317-333. - doi: 10.1023/A:1005157509454

Dumitrescu A, Birsan MV (2015). ROCADA: a gridded daily climatic dataset over Romania (19612013) for nine meteorological variables. Natural Hazards 78 (2): 1045-1063. - doi: 10.1007/s11069015-1757-z

Eichhorn J, Szepesi A, Ferretti M, Durrant D, Roskams P (2006). Visual assessment of crown condition. Manual Part II. In: "Manual on Methods and Criteria for Harmonized Sampling, Assessment, Monitoring and Analysis of the Effects of Air Pollution on Forests". UNECE-ICP Forests Programme Co-ordinating Centre, Hamburg, Germany, pp. 61.

Eichhorn J, Roskams P, Ferretti M, Mues V, Szepesi A, Durrant D (2010). Visual assessment of crown condition and damaging agents. Manual Part IV. In: “Manual on Methods and Criteria for Harmonized Sampling, Assessment, Monitoring and Analysis of the Effects of Air Pollution on Forests". UNECE-ICP Forests Programme Co-ordinating Centre, Hamburg, Germany, pp. 49.

Ferretti M, Nicolas M, Bacaro G, Brunialti G, Calderisi $M$, Croisé L, Frati L, Lanier M, Maccherini S, Santi E, Ulrich E (2014). Plot-scale modelling to detect size, extent, and correlates of changes in tree defoliation in French high forests. Forest Ecology and Management 311: 5669. - doi: 10.1016/j.foreco.2013.05.009

Fischer R, Waldner P, Carnicer J, Coll M, Dobbertin $M$, Ferretti $M$, Hansen $K$, Kindermann $G$, Lasch-Born P, Lorenz M, Marchetto A, Meining
S, Nieminen T, Peñuelas J, Rautio P, Reyer C, Roskams P, Sánchez G (2012). The condition of forests in Europe: 2012 Executive Report. ICP Forests, Hamburg, Germany, pp. 24. [online] URL: http://www.icp-forests.org/pdf/ER2012.pd

Fischer R, Lorenz M, Granke O, Mues V, lost S, Van Dobben H, Reinds GJ, De Vries W (2010). Forest condition in Europe: 2010 Technical Report of ICP Forests. Work Report of the Institute for World Forestry 2010/1, ICP Forests, Hamburg, Germany, pp. 175. [online] URL: http://library.wur.nl/WebQuery/wurpubs/fulltex $\mathrm{t} / 160482$

Green RE, Cornell SJ, Scharlemann JP, Balmford A (2005). Farming and the fate of wild nature. Science 307 (5709): 550-555. - doi: 10.1126/scien ce. 1106049

Henry PY, Lengyel S, Nowicki P, Julliard R, Clobert J, Celik T, Gruber B, Schmeller DS, Babij $\mathrm{V}$ (2008). Integrating ongoing biodiversity monitoring: potential benefits and methods. Biodiversity and Conservation 17 (14): 3357-3382. doi: 10.1007/s10531-008-9417-1

IPCC (2013). Climate change 2013: the physical science basis. Contribution of Working Group I to the Fifth Assessment Report of the Intergovernmental Panel on Climate Change. Cambridge University Press, Cambridge, UK and New York, NY, USA, pp. 1535.

Kraft G (1884). Beiträge zur Lehre von den Durchforstungen, Schlagstellungen und Lichtungshieben [Contributions to thinnings, order of cutting and light felling]. Klindworth's, Hannover, Germany, pp 147. [in German]

Matthews E, Payne R, Rohweder M, Murray S (2000). Pilot analysis of global ecosystems: forest ecosystems. World Resources Institute, Washington, DC, USA, pp. 86. [online] URL: http://www.cabdirect.org/cabdirect/abstract/2 0013071987

MEa (2005). Ecosystems and human well-being (vol. 5). Millenium Ecosystem Assessment, Island Press, Washington, DC, USA, pp. 155.

Michel A, Seidling W (2014). Forest condition in Europe. 2014 Technical Report of ICP Forests. Report under the UNECE Convention on LongRange Transboundary Air Pollution (CLRTAP). BFW Austrian Research Centre for Forests, BFW-Dokumentation 18/2014, Vienna, Austria, pp. 164. [online] URL: http://s3.amazonaws. com/academia.edu.documents/43196092/ Nevalainen S, Yli-Kojola $\mathrm{H}$ (2000). Extent of abiotic damage and its relation to defoliation of conifers in Finland. Forest Ecology and Management 135 (1-3): 229-235. - doi: 10.1016/S03781127(00)00313-3

Nowak DJ, Hirabayashi S, Bodine A, Greenfield E (2014). Tree and forest effects on air quality and human health in the United States. Environmental Pollution 193: 119-129. - doi: 10.1016/j. envpol.2014.05.028

Obersteiner M, Böttcher H, Yamagata Y (2010). Terrestrial ecosystem management for climate change mitigation. Current Opinion in Environmental Sustainability 2 (4): 271-276. - doi: 10.101 6/j.cosust.2010.05.006

Ojea E, Nunes PALD, Loureiro ML (2010). Mapping biodiversity indicators and assessing biodiversity values in global forests. Environmental and Resource Economics 47 (3): 329-347. - doi: 10.1007/s10640-010-9381-6

Ozolincius R, Stakenas V, Serafinaviciute B (2005). Meteorological factors and air pollution in Lithuanian forests: possible effects on tree condition. Environmental Pollution 137 (3): 587595. - doi: 10.1016/j.envpol.2005.01.044

Paltineanu C, Mihailescu I, Prefac Z, Dragota C, Vasenciuc F, Claudia N (2009). Combining the standardized precipitation index and climatic water deficit in characterizing droughts: a case study in Romania. Theoretical and Applied Climatology 97 (3-4): 219-233. - doi: 10.1007/s0070 4-008-0061-1

Petersen J, Elbersen B, Wiesenthal T, Feehan J, Eppler U (2007). Estimating the environmentally compatible bioenergy potential from agriculture. European Environmental Agency, Copenhagen, Denmark, pp. 138.

Requardt A, Schuck A, Köhl M (2009). Means of combating forest dieback-EU support for maintaining forest health and vitality. iForest 2 (1): 38-42. - doi: 10.3832/iforo480-002

Schaich H, Milad M (2013). Forest biodiversity in a changing climate: which logic for conservation strategies? Biodiversity and Conservation 22 (5): 1107-1114. - doi: 10.1007/s10531-013-0491-7 R Core Team (2008). R: a language and environment for statistical computing. R Foundation for Statistical Computing, Vienna, Austria. [online] URL: http://www.r-project.org

Yoshikawa M, Motoki Y, Hibino G, Takeuchi K, Hanaki K, Arai S, Masui T, Inoue T (2011). Globalscale quantitative assessment for biodiversity on forest land use: applying the global no net loss approach. Sustainability Science 6 (2): 169175. - doi: 10.1007/s11625-011-0128-2 